\title{
USEFULNESS OF BASE DEFICIT IN THE ASSESSMENT OF SERUM LACTATE LEVELS IN CRITICALLY ILL PATIENTS ON MECHANICAL VENTILATION
}

Milos Novovic, Filip Zunic, Marija Jankovic and Jasna Jevdjic

Center for Anesthesia and Resuscitation, Clinical center Kragujevac, Kragujevac, Serbia

\author{
KORISNOST BAZNOG DEFICITA U PREDIKCIJI VREDNOSTI \\ SERUMSKIH LAKTATA KOD KRITIČNO OBOLELIH BOLESNIKA \\ NA MEHANIČKOJ VENTILACIJI \\ Miloš Novović, Filip Žunić, Marija Janković i Jasna Jevđić \\ Centar za anesteziju i resuscitaciju, Klinički centar Kragujevac, Kragujevac, Srbija
}

\section{ABSTRACT}

Background/aim: Acid-base disturbances are common in critically ill patients. Some of the most commonly used markers of metabolic acidosis are base deficit and lactate. The aim of this study was to evaluate the correlation between base deficit and serum lactate and the utility of base deficit in the assessment of serum lactate levels in critically ill patients on mechanical ventilation.

Methods: This study was designed as a retrospective, analytical study. We reviewed all arterial gas analyses (base deficit and lactate levels) of patients on mechanical ventilation. The correlation between base deficit and lactate was assessed by calculation of the Pearson correlation coefficient ( $r$ ) and coefficient of determination $\left(R^{2}\right)$. Receiver operating characteristic (ROC) curves were created for base deficit to detect the presence of hyperlactatemia. The SPSS 12.0 software package (Chicago, Illinois) was used for statistical analyses.

Results: One hundred forty-two patients participated in the study: including survivors $(n=68)$ and non-survivors $(n=74)$. The mean value of base deficit was $0.512 \pm 6.10 \mathrm{mmol} / \mathrm{L}$, and the mean value of serum lactate was $2.04 \pm 2.07 \mathrm{mmol} / \mathrm{L}$. There was no difference in lactate and base deficit values between the groups ( $p=0.101, p=0.106$, respectively). Hyperlactatemia was observed in 44 patients (30.98\% ). In ROC curve analysis, the area under the curve for base deficit to detect hyperlactatemia was 0.527.

Conclusion: This study indicates that base deficit is not an appropriate marker in the evaluation of real serum lactate values.

Keywords: Base deficit, Serum lactate, Critically ill, Metabolic acidosis

\section{SAŽETAK}

Uvod/Cilj: Acido-bazni poremećaji su uobičajeni kod kritično obolelih pacijenata. Neki od najčešće korišćenih markera metaboličke acidoze su bazni deficit i serumski laktati. Cilj ove studije je bio da se ispita povezanost izmedu baznog deficita $i$ serumskih laktata, kao i korisnost baznog deficita u procenjivanju vrednosti serumskih laktata kod kritično obolelih pacijenata na mehaničkoj ventilaciji.

Metode: Studija je dizajnirana kao retrospektivna, analitička studija. Pregledali smo sve arterijske gasne analize pacijenata na mehaničkoj ventilaciji, kojima su određivani bazni deficit $i$ laktati. Korelacija izmedu baznog deficita $i$ laktata procenjivana je pomoću Pearsonovog koeficijenta korelacije ( $r$ ) i koeficijenta determinacije $\left(R^{2}\right)$. ROC krive su konstruisane za bazni deficit radi procene prisustva hiperlaktatemije. Za statističku obradu podataka korišćen je SPSS 12.0 (Čikago, Ilinois) softverski paket.

Rezultati: 142 pacijenta, preživeli $(n=68)$ i umrli $(n=74)$. Srednja vrednost baznog deficita bila je $0.512 \pm 6.10$ mmol/L; srednja vrednost serumskih laktata bila je $2.04 \pm$ $2.07 \mathrm{mmol} / \mathrm{L}$. Nije bilo statistički značajne razlike izmeðu grupa za laktate $i$ bazni deficit ( $p=0.101, p=0.106$ redom). Hiperlaktatemija je primećena kod 44 pacijenta (30,98\%). ROC površina ispod krive za bazni deficit da otkrije hiperlaktatemiju bila je 0.527.

Zaključak: Ova studija ukazuje da bazni deficit nije adekvatan marker u evaluaciji stvarnih vrednosti serumskih laktata.

Ključne reči: Bazni deficit, Serumski laktati, Kritično oboleli, Metabolička acidoza

\section{ABBREVIATIONS:}

APACHE II- Acute Physiology And Chronic Health Evaluation; AUC-Area under the curve;
BD- Base deficit;

ICU- Intensive care unit;

ROC- Receiver operating characteristic

We are grateful to Valentina Rizvić on technical assistance in the preparation of manuscript. 


\section{INTRODUCTION}

Acid-base disturbances are common in critically ill patients. Understanding these disorders is of great importance in intensive care medicine. Early identification and correction of acid-base disorders play a major role in the treatment of critically ill patients [1]. Some of the most commonly used markers of metabolic acidosis are base deficit (BD) and lactate $[2,3]$.

Calculation of BD is performedcarried out with a blood gas analyser using measured $\mathrm{PaCO}_{2}$ and $\mathrm{pH}$ values as applied to a standard nomogram, and $\mathrm{BD}$ represents the number of milliequivalents $(\mathrm{mEq})$ of additional base that must be added to a litre of blood to normalise the $\mathrm{pH}$. An elevated BD represents the presence of unmeasured anions and this is usually taken as a surrogate marker of lactic acidosis $[4,5]$. BD is a sensible and easy tool to disclose clinically significant metabolic acidosis [6]. Many authors have shown that $\mathrm{BD}$ values correlate with the development of multiple organ failure and mortality [7,8,9]. Other authors have shown that BD should be used with caution as a marker of shock and resuscitation of shock [10].

Metabolic parameters such as lactate are minimally invasive measures of systemic oxygen transport. Hypoxia and hypoperfusion in critically ill patients leads to lactic acid production, with consequent lactic acidosis, which is why lactate is often considered as a marker of tissue hypoxia $[3,10,19]$. Additionally, serum lactate levels may be elevated as a result of inflammation and increased rates of glycolysis caused by stress $[3,11]$. It has been shown that hyperlactatemia (lactate values greater than $2 \mathrm{mmol} / \mathrm{L}$ ) was associated with increased mortality in patients with shock, trauma, and sepsis $[12,13,14,15,16]$. However, many hospitals still have blood gas analysers that analyse only $\mathrm{BD}$ and not lactate (18). Considering that the value of BD can be reversed by therapeutic procedures, such as the administration of large amounts of saline solution, BD does not always correlate with serum lactate levels in critically ill patients $[10,17]$.

The aim of this study was to evaluate the correlation between $\mathrm{BD}$ and serum lactate and to determine the utility of $\mathrm{BD}$ in the assessment of serum lactate levels in critical ill patients on mechanical ventilation.

\section{MATERIAL AND METHODS}

This study was designed as a retrospective, analytical study. It involved a subpopulation of critically ill patients on mechanical ventilation that were admitted to the intensive care unit, Clinical Centre Kragujevac, during the period between January 2012 and October 2012. The intensive care unit was equipped with 17 beds, screens for continuous monitoring of vital functions, 10 devices for mechanical ventilation, and one blood gas analyser. The intensive care unit is a polyvalent type and, at the same time, is a primary place in the hospital for providing medical help in the case of polytrauma and especially in the case of neurotrauma after initial treatment in the emergency centere. The study was approved by the ethics committee of the Clinical Centre Kragujevac. Criteria for including patients in the study were the following: patients that needed mechanical ventilation and intensive monitoring of vital parameters (e.g., EKG monitoring, body temperature, and arterial blood pressure). It was necessary that arterial gas analyses and biochemical analyses were performed on the admission date at the intensive care unit. Exclusion criteria were as follows: patients under 18 years of age, patients admitted due to poisoning, and patients diagnosed with cancer.

According to outcomes, patients were divided into two groups: survivors and non-survivors. To establish the mortality rate, all of the patients were monitored during a 28-day period from the moment of admission to the intensive care unit. Demographic data, admission diagnosis, APACHE II score values within first 48 hours of admission (Acute Physiology And Chronic Health Evaluation) and treatment outcome (survivor or non-survivor) were collected from case histories and discharge notes of patients involved in the study. Venous blood was collected through a cannula introduced for therapy application. Different veins in the forearm were used for blood draws. Arterial blood was sampled from the radial artery. Arterial puncture was performed with a syringe and needle (2426) which were covered with heparin as anticoagulant. All samples were analysed with a gas analyser (GEM Premier 3000). Biochemical parameters were analysed with a biochemical analyser (Ilab 600) in the laboratory of the Clinical Centre Kragujevac.

Sample size was calculated using the Sample Size Correlation Program, based on results obtained from the study performed by Chawla in 2010 [17]. An adequate sample size to detect an assumed correlation of 0.27 with power $1-\beta=0.8$ and error level $\alpha=0.05$ was calculated as 83 patients.

Descriptive and analytical statistical methods were used in the study. The following descriptive methods were used calculation of absolute and relative numbers, central trend measures (arithmetic mean and median), and dispersion measures (standard deviation [SD]). The following analytical methods were used: T-test and Mann-Whitney $\mathrm{U}$ test. The correlation between $\mathrm{BD}$ and lactate was assessed by calculating the Pearson correlation coefficient $(\mathrm{r})$ and the coefficient of determination $\left(\mathrm{R}^{2}\right)$. Receiver operating characteristic (ROC) curves were created for BD to detect the presence of hyperlactatemia. The SPSS 12.0 software package (Chicago, Illinois) was used for statistical analyses.

\section{RESULTS}

There were 142 subjects enrolled in the study including (67 men and 75 women). Ninety-one (64.1\%) of these patients 


\begin{tabular}{|c|c|}
\hline $\mathbf{N}$ & 142 \\
\hline Age (mean, SD) & $60.4 \pm 16.98$ \\
\hline Sex (male) & $67(47.2 \%)$ \\
\hline \multicolumn{2}{|l|}{ Reasons for ICU admission: } \\
\hline Postoperative neurosurgical & $33(23.2 \%)$ \\
\hline Postoperative surgical & $53(37.3 \%)$ \\
\hline Polytrauma & $11(7.7 \%)$ \\
\hline Neurological & $13(9.1 \%)$ \\
\hline Respiratory failure & $17(11.9 \%)$ \\
\hline Sepsis & $10(7.1 \%)$ \\
\hline Post-cardiac arrest & $5(3.5 \%)$ \\
\hline Survivors/Non-survivors & $68(47.9 \%) / 74(52.1 \%)$ \\
\hline APACHE II (mean, SD) & $16.23 \pm 6.44$ \\
\hline $\mathrm{FiO}_{2} \%$ (mean, SD) & $42.2 \pm 12.97$ \\
\hline $\mathrm{PaO}_{2} \mathrm{kPa}$ (mean, SD) & $1.77 \pm 3.85$ \\
\hline $\mathrm{PaCO}_{2} \mathrm{kPa}$ (mean, SD) & $5.98 \pm 1.85$ \\
\hline Hct (mean, SD) & $0.31 \pm 0.067$ \\
\hline MAP mm Hg (mean, SD) & $86.05 \pm 34.63$ \\
\hline $\mathrm{Na}^{+} \mathrm{mmol} / \mathrm{L}$ (mean, SD) & $140.27 \pm 9.07$ \\
\hline $\mathrm{K}^{+} \mathrm{mmol} / \mathrm{L}$ (mean, SD) & $3.91 \pm 0.81$ \\
\hline $\mathrm{pH}($ mean, SD) & $7.36 \pm 0.103$ \\
\hline $\mathrm{HCO}_{3} \mathrm{mmol} / \mathrm{L}($ mean, SD) & $22.34 \pm 5.68$ \\
\hline $\mathrm{BD}$ mmol/L (mean, SD) & $0.512 \pm 6.10$ \\
\hline Lactates $\mathrm{mmol} / \mathrm{L}$ & $2.04 \pm 2.07$ \\
\hline Hyperlactatemia n (\%) & $44(31 \%)$ \\
\hline Albumin g/l (mean, SD) & $26.54 \pm 6.19$ \\
\hline
\end{tabular}

Table 1. Demographic data and average values

APACHE II- Acute Physiology And Chronic Health Evaluation; $\mathrm{FiO}_{2-}$ Fraction of inspired oxygen; $\mathrm{PaO}_{2}-$ partial pressure of oxygen; $\mathrm{PaCO}_{2}$ partial pressure of carbon-dioxide; Hct- hematocrit; MAP- mean arterial pressure; $\mathrm{BD}$ - Base deficit; $\mathrm{HCO}_{3}$ - Bicarbonate; SD- Standard deviation.

were admitted to the ICU after surgery, and 51 (35.9\%) patients were admitted with other urgent medical conditions. The APACHE II score on admission to the intensive care unit for the entire sample was $16.23 \pm 6.44$. There was a statistically significant difference in APACHE II scores $(t=5.802 ; \mathrm{p}<0.001)$ between the groups. Detailed information about average values and demographic data are given in Table 1.

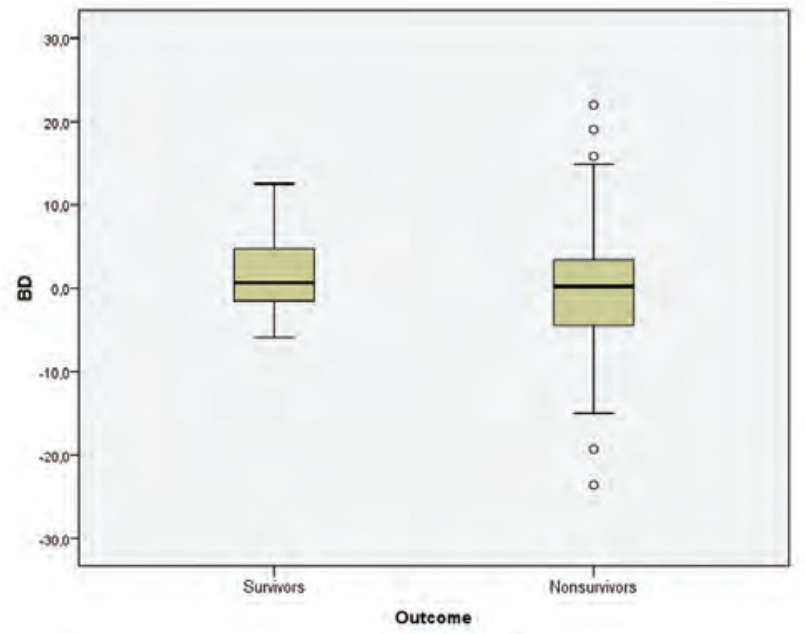

Figure 1. Boxplot of base deficit (BD) levels in the survivor and nonsurvivor groups.

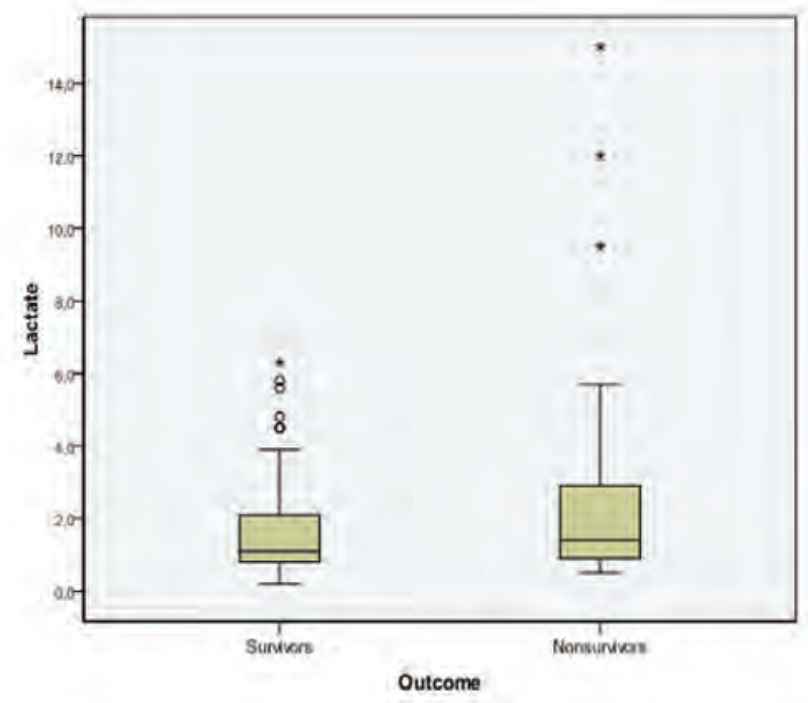

Figure 2. Boxplot of lactate levels in the survivor and non-survivor groups.

The mean $\mathrm{BD}$ value was $0.512 \pm 6.10$, and the mean serum lactate value was $2.04 \pm 2.07$. There was no difference in lactate levels $(\mathrm{U}=2115.5 ; \mathrm{Z}=-1.638 ; \mathrm{p}=0.101)$ and $\mathrm{BD}$ values $(\mathrm{U}=2120 ; \mathrm{Z}=-1.617 ; \mathrm{p}=0.106)$ between the groups. The mean $B D$ values and lactate levels in the survivor and non-survivor groups are shown in Figures 1 and 2. Of the 142 patients that were included in the study, hyperlactatemia was observed in

\begin{tabular}{|ll|l|l|l|l|}
\hline & & BD & Lactate & pH & HCO3 \\
\hline BD & Pearson Correlation & & 0.053 & $0.188^{* *}$ & $0.442^{* * *}$ \\
& Sig. (2-tailed) & & 0.532 & 0.025 & 0.000 \\
\hline Lactate & $\begin{array}{l}\text { Pearson Correlation } \\
\text { Sig. (2-tailed) }\end{array}$ & 0.053 & & $-0.518^{* * *}$ & $-0.396^{* * *}$ \\
& 0.532 & & 0.000 & 0.000 \\
\hline $\mathrm{pH} \quad$ Pearson Correlation & $0.188^{* *}$ & & $0.549^{* * *}$ \\
& Sig. (2-tailed) & 0.025 & $-0.518^{* * *}$ & & 0.000 \\
\hline $\mathrm{HCO}_{3} \quad \begin{array}{l}\text { Pearson Correlation } \\
\text { Sig. (2-tailed) }\end{array}$ & $0.442^{* * *}$ & 0.000 & $-0.396^{* * *}$ & $0.549^{* * *}$ & \\
\hline
\end{tabular}

Table 2. Correlations

BD- base deficit; HCO3- bicarbonate; "Correlation is significant at the 0.05 level (2-tailed); ${ }^{* *}$ Correlation is significant at the 0.01 level (2-tailed). 


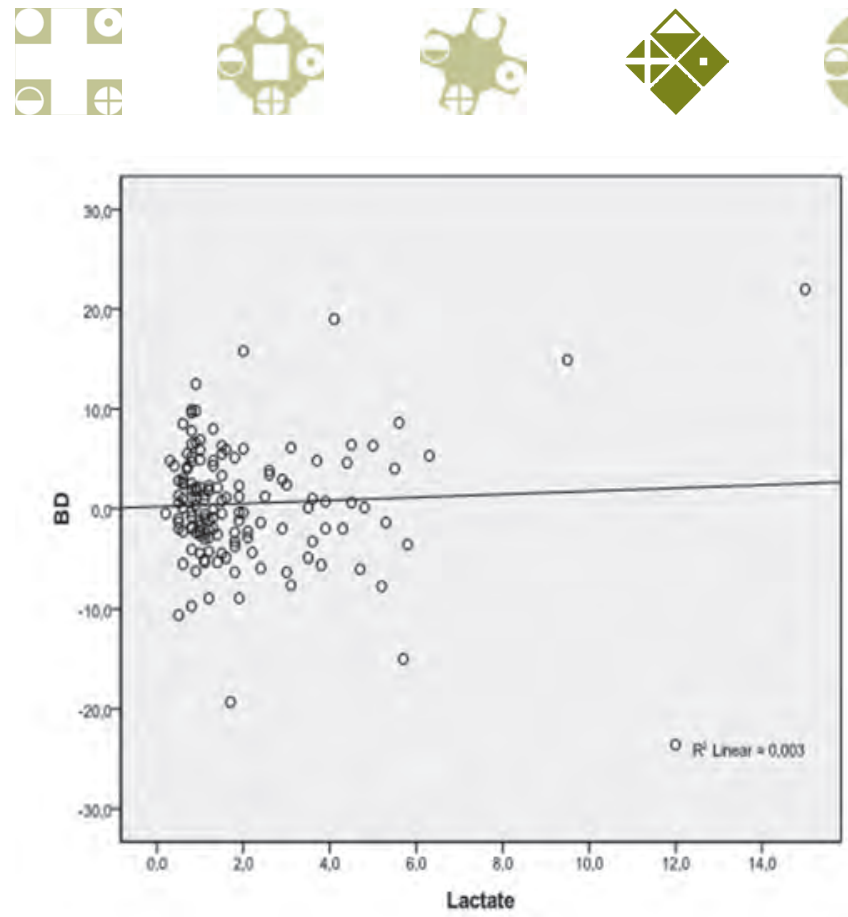

Figure 3. Scatterplot of base deficit (BD) vs lactate level

44 patients (30.98\%). The results of Pearson's correlation between studied variables are presented in Table 2. The correlation of BD compared with lactate is shown in Figure 3. In the ROC curve analysis, the area under the curve for BD to detect hyperlactatemia was 0.527 (Figure 4).

\section{DISCUSSION}

This study explored the correlation between the two most commonly used markers of acid-base disturbances in critically ill patients: the value value of BD and serum

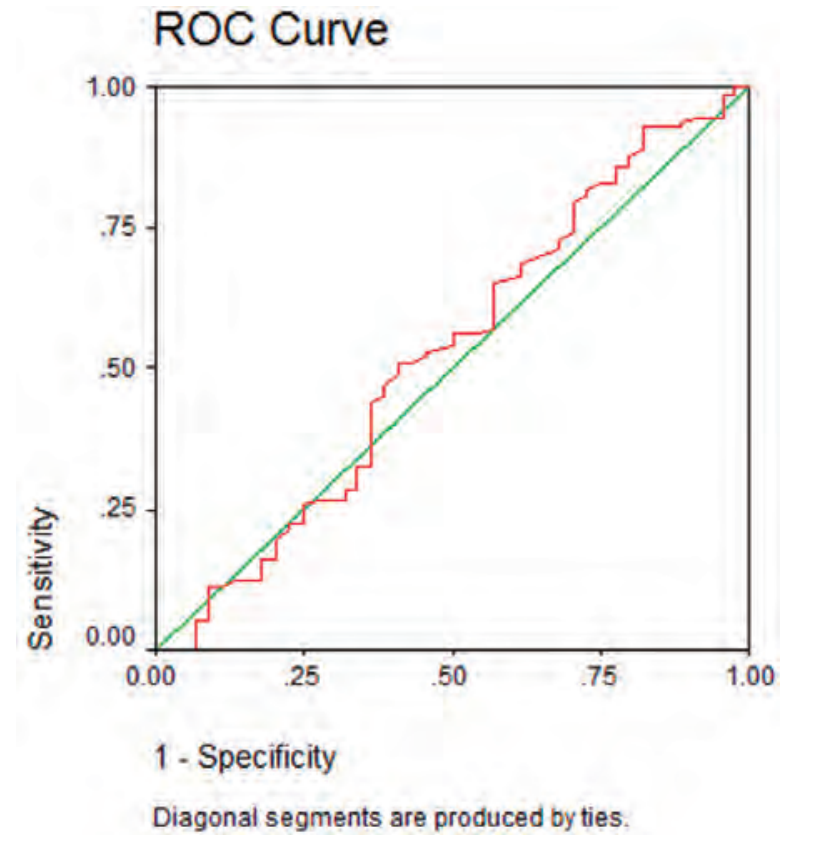

Figure 4. Receiver operating characteristic (ROC) curve for the prediction of hyperlactatemia by the base deficit (BD) level. Area under curve $(\mathrm{AUC})=0.527$. lactate. Metabolic acidosis remains one of the most common acid-base disorders and often marks the beginning of tissue hypoxia and organ hypoperfusion $[6,7,10,18]$. Serum lactate levels have been used to detect the presence of tissue hypoperfusion and as a prognosticating marker in different subgroups of patients [3, 8, 10, 12, 13].

In the present study, the incidence of hyperlactatemia on admission to the intensive care unit was $30.98 \%$, but there were no statistically significant differences in lactate and BD levels between the survivor and non-survivor groups $(p>0.01)$. In a population of patients that were admitted to a surgical intensive care unit, Matthew et al. showed that lactic acidosis was present in $41 \%$ of the patients. In their study, non-survivors had higher lactate and $\mathrm{BD}$ values than survivors. They also showed that an increased $\mathrm{BD}$ level had no predictive value if the lactate level was normal [19]. In the study conducted by Chawla et al., in the group of patients undergoing general anaesthesia, hyperlactatemia was observed in $40 \%$ of the patients. It was shown that the use of BD can often mislead the clinician as to the actual serum lactate concentration [17].

However, we found that the ROC area under the curve for $\mathrm{BD}$ in predicting hyperlactatemia was 0.527 , which implies it is a very weak tool as a substitute for serum lactate. These results support the results of other similar studies in which the BD was evaluated as a surrogate marker for hyperlactatemia in critically ill patients $[3,6,17,19]$. It should be mentioned that this study is the first focused on critically ill patients on mechanical ventilation exclusively. Some studies have shown that, despite a normal BD and lack of acidosis, significant hyperlactatemia and dangerous hypoperfusion states can exist. This was explained by the variety of mechanisms underlying hyperlactataemia in critically ill patients $[12,18,20]$.

Our study had certain limitations. We did not have accurate data about types and amount of fluids that were used for resuscitation before admission to the ICU. Additionally, the scope of different diagnoses in this study was very heterogeneous. We suggest that future studies dealing with this phenomenon should focus on patients with a clearly defined diagnosis (e.g., surgical, neurosurgical, neurological or internist-determined) and precisely identified type and amount of fluids that were used in resuscitation efforts.

In conclusion, we demonstrated that hyperlactatemia is a common finding in critically ill patients on mechanical ventilation. The aim of any therapy is restitution of global tissue hypoxia. A decrease in lactate values to normal levels allows this restitution. As shown in this study, the use of BD instead of serum lactate is not desirable. This study indicates that $\mathrm{BD}$ is not appropriate in the evaluation of real values of serum lactate.

\section{REFERENCES}

1. Wilson RF, Sibbald WJ. Approach to acid-base problems in the critically ill and injured. J Am Coll Emerg Phys 1976;5:515-22. 
2. Siggaard-Andersen O: The van Slyke equation. ScandJ ClinLab Invest Suppl 1977; 37:15-20.

3. Aduen J, Bernstein WK, Miller J, et al. Relationship between blood lactate concentrations and ionized calcium, glucose, and acid-base status in critically ill and noncritically ill patients. Crit Care Med 1995;23:246 -52.

4. Balasubramanyan N, Havens PL, Hoffman GM. Unmeasured anions identified by the Fencl-Stewart method predict mortality better than base excess, anion gap, and lactate in patients in the pediatric intensive care unit. Crit Care Med 1999;27:1577-81.

5. Fencl V, Jabor A, Kazda A, Figge J. Diagnosis of metabolic acid-base disturbances in critically ill patients. Am J Respir Crit Care Med 2000;162:2246 -51.

6. Park M, Taniguchi LU, Noritomi DT, Libório AB, Maciel AT, Cruz-Neto LM. Clinical utility of standard base excess in the diagnosis and interpretation of metabolic acidosis in critically ill patients. Braz J Med Biol Res. 2008;41:241-9.

7. Maciel AT, Park M. Differences in acid-base behavior between intensive care unit survivors and nonsurvivors using both a physicochemical and a standard base excess approach: a prospective, observational study. J Crit Care. 2009;24:477-83.

8. Ouellet JF, Roberts DJ, Tiruta C, Kirkpatrick AW, Mercado M, Trottier V, Dixon E, Feliciano DV, Ball CG. Admission base deficit and lactate levels in Canadian patients with blunt trauma: are they useful markers of mortality? J Trauma Acute Care Surg. 2012;72:1532-5.

9. Sauaia A, Moore FA, Moore EE, et al. Early predictors of postinjury multiple organ failure. Arch Surg 1994;129:39-45.

10. Husain F, Martin M, Mullenix P, Steele S, Elliott D. Serum lactate and base deficit as predictors of mortality and morbidity. Am J Surg. 2003;185:485-491.
11. Gutierrez G, Wulf ME. Lactic acidosis in sepsis: another commentary. Crit Care Med. 2005;33:2420-2422.

12. Juneja D, Singh O, Dang R: Admission hyperlactatemia: causes, incidence, and impact on outcome of patients admitted in a general medical intensive care unit. J Crit Care. 2011;26:31-20.

13. Fuller BM, Dellinger RP. Lactate as a hemodynamic marker in the critically ill. Curr Opin Crit Care. 2012 Jun;18(3):267-72.

14. Trzeciak S, Dellinger RP, Chansky ME, et al. Serum lactate as a predictor of mortality in patients with infection. Intensive Care Med 2007; 33:970-977.

15. Mikkelsen ME, Miltiades AN, Gaieski DF, et al. Serum lactate is associated with mortality in severe sepsis independent of organ failure and shock. Crit Care Med 2009; 37:1670-1677.

16. Fall PJ, Szerlip HM. Lactic acidosis: from sour milk to septic shock. J Intensive Care Med 2005; 20:255-271.

17. Chawla LS, Nader A, Nelson T, Govindji T, Wilson R, Szlyk S, Nguyen A, Junker C, Seneff MG. Utilization of base deficit and reliability of base deficit as a surrogate for serum lactate in the peri-operative setting. BMC Anesthesiol. 2010;10:16.

18. Smith I, Kumar P, Molloy S, Rhodes A, Newman PJ, Grounds RM, Bennett ED. Base excess and lactate as prognostic indicators for patients admitted to intensive care. Intensive Care Med. 2001;27:74-83.

19. Martin MJ, FitzSullivan E, Salim A, Brown CV, Demetriades D, Long W. Discordance between lactate and base deficit in the surgical intensive care unit: which one do you trust? Am J Surg. 2006;191:625-30.

20. Mikulashek A, Henry SM, Donovan R, et al. Serum lactate is not predicted by anion gap or base excess after trauma resuscitation. J Trauma 1996;40:218-22. 